\title{
Pengaruh Model Pembelajaran Childrens Learning In Science Berbantuan Media Lingkungan terhadap Hasil Belajar IPA
}

\author{
Anak Agung Istri Dias Andrayani1 ${ }^{*}$, Ni Wayan Suniasih ${ }^{2}$, I Wayan Warta ${ }^{3}$
}

1,2,3Jurusan Pendidikan Guru Sekolah Dasar, FIP, Universitas Pendidikan Ganesha, Singaraja, Indonesia

\author{
A RTICLEINFO \\ Article history: \\ Received 17 Desember \\ 2017 \\ Received in revised form \\ 28 Desember 2017 \\ Accepted 28 Januari 2018 \\ Available online 20 \\ Februari 2018

\begin{tabular}{l}
\hline Kata Kunci: \\
CLIS, \\
Lingkungan, \\
Hasil Belajar IPA \\
Keywords: \\
CLIS, \\
Environment, \\
Scientific Learning Results
\end{tabular}

\begin{abstract}
A B S T R A K
Penelitian ini bertujuan untuk mengetahui pengaruh model pembelajaran Children's Learning In Sciece (CLIS) berbantuan media lingkungan terhadap hasil belajar IPA siswa yang dibelajarkan melalui model pembelajaran CLIS berbantuan media lingkungan dan siswa yang dibelajarkan melalui pembelajaran konvensional pada siswa kelas IV SD Gugus 1 Kuta Utara Tahun Ajaran 2016/2017. Penelitian ini merupakan penelitian eksperimen dengan desain eksperimen yang digunakan adalah Pre-Experimental Designs. Rancangan desain yang digunakan yaitu Intact-Group Comparison. Populasi dalam penelitian ini adalah seluruh siswa kelas IV. Sampel penelitian ini adalah siswa kelas IV SD No. 5 Dalung sebagai kelas eksperimen dan siswa kelas IV SD No. 6 Dalung sebagai kelas kontrol dengan jumlah masing-masing kelompok sebanyak 36 siswa. Metode pengumpulan data dalam penelitian ini adalah metode tes, dengan tes pilihan ganda biasa yang berjumlah 28 butir soal yang telah di validasi. Analisis data menunjukkan terdapat perbedaan yang signifikan hasil belajar IPA
\end{abstract} siswa yang dibelajarkan melalui model pembelajaran CLIS berbantuan media lingkungan dan siswa yang dibelajarkan melalui pembelajaran konvensional pada siswa kelas IV ( thitung $=2,96>t_{\text {tabel }}=2,000$ ) dengan rerata nilai hasil belajar IPA siswa yang dibelajarkan melalui model pembelajaran CLIS berbantuan media lingkungan $\bar{X}=83,83$ dan siswa yang dibelajarkan melalui pembelajaran konvensional $\bar{X}=74,33$. Dengan demikian, dapat disimpulkan bahwa model pembelajaran Children's Learning In Sciece (CLIS) berbantuan media lingkungan berpengaruh terhadap hasil belajar IPA siswa kelas IV SD Gugus 1 Kuta Utara Tahun Ajaran 2016/2017.

\section{A B S T R A C T}

This study aimed to determine the effect of Children's Learning In Scientific learning model, which is assisted by environmental media to the student's scient learning outcomes learned through the CLIS model with the help of environmental media and students Taught through conventional learning in fourth grade students SD Gugus 1 Kuta Utara 2016/2017. This research is an experimental research with experimental design which is used is a pre-experimental designs with pre-experimental designs. The population in this study were all fourth graders. The sample of this research is the fourth grade students of SD No. 5 Dalung as experiment class and the fourth grade students of SD No. 6 Dalung as control class with the number of each group is 36 students. The method of data collection in this study is the test method, with the usual double-choice test of 28 validated items. The data analysis shows that there are significant differences in students' learning outcomes learned through the CLIS model of assisted environment media and students taught through conventional learning in fourth graders (thitung $=2,96>$ ttable $=2.00$ ) with mean learning outcomes of science students studied through the CLIS model with the help of environmental media $=83.83$ and students taught through conventional learning $=74.33$. Thus it can be concluded that the learning model of Children's Learning In Scientific (CLIS) with the help of environmental media has an effect on the science learning outcomes of fourth grade students of SD Gugus North Kuta, Badung Regency, Academic Years 2016/2017. 


\section{Pendahuluan}

Secara formal dan institusional, sekolah dasar masuk pada kategori pendidikan dasar. Pendidikan dasar menurut Undang-Undang Sistem Pendidikan Nasional No.20 Tahun 2003 Pasal 17 ayat 1 dan 2 merupakan jenjang pendidikan yang dilandasi jenjang menengah; pendidikan dasar berbentuk sekolah dasar (SD) dan madrasah ibtidaiyah (MI) atau bentuk lain yang sederajat serta sekolah menengah pertama (SMP) dan madrasah tsanawiyah (MTs), atau bentuk lain yang sederajat (Susanto, 2015:69).

Jadi pendidikan dasar yang dimaksudkan dalam Undang-Undang No.20 Tahun 2003 tersebut adalah pendidikan yang berbentuk sekolah dasar atau madrasah ibtidaiyah dan sekolah menengah pertama atau madrasah tsanawiyah. Pendidikan dasar tersebut tidak hanya pendidikan dasar di sekolah dasar saja, tetapi juga pada sekolah menengah pertama. Pendidikan dasar berfungsi sebagai peletakan dasar-dasar keilmuan dan membantu mengoptimalkan perkembangan siswa melalui pembelajaran yang dibimbing oleh guru.

Keberhasilan dalam menyampaikan materi saat proses belajar berlangsung, sangat tergantung pada kelancaran interaksi komunikasi antara guru dengan siswanya. Seorang guru memiliki tiga peran utama untuk meningkatkan proses pembelajaran yakni; peran sebagai perencana pembelajaran, peran sebagai pengelola pembelajaran dan sebagai penilai keberhasilan belajar siswa. Dalam merancang pembelajaran, harus memperhatikan tujuan diselenggarakannya pembelajaran itu sendiri, termasuk di dalam pembelajaran Ilmu Pengetahuan Alam (IPA).

Ilmu pengetahuan alam (IPA) atau sains dalam arti sempit sebagai disiplin ilmu dari physical sciences dan life sciences, yang termasuk physical sciences adalah ilmu-ilmu astronomi, kimia, geologi, mineralogi, meteorologi, dan fisika; sedangkan life science meliputi biologi (anatomi, fisiologi, zoologi, citologi dan seterusnya) Samatowa (2011:1). Jadi ilmu pengetahuan alam (IPA) atau science pengertiannya dapat disebut sebagai ilmu tentang alam. Ilmu yang mempelajari tentang peristiwaperistiwa yang terjadi di alam ini. Mata pelajaran IPA merupakan mata pelajaran yang selama ini dianggap sulit oleh sebagian besar peserta didik, mulai dari jenjang sekolah dasar sampai sekolah menengah.

Berdasarkan hasil observasi yang dilakukan pada tanggal 3 Januari 2017 terdapat temuan yaitu belum banyak siswa yang aktif bertanya saat pembelajaran berlangsung, dan pada mata pelajaran IPA yang dipelajari kurang dikaitkan dengan kehidupan sehari-hari. Pembelajaran yang berlangsung di sekolah selama ini masih kurang mampu untuk mendorong siswa mengembangkan kemampuan berpikirnya. Pembelajaran di dalam kelas cenderung diarahkan pada kemampuan siswa untuk menghafal informasi dan menimbun informasi, tanpa berusaha untuk menghubungkan dalam kehidupan seharihari. Hal ini menyebabkan kurang termotivasinya siswa dalam belajar dan menyebabkan siswa kurang memahami pelajaran yang diajarkan oleh guru, sehingga siswa tidak dapat mencapai hasil belajar yang ditetapkan sekolah. Kondisi tersebut juga terjadi pada mata pelajaran IPA (Susanto, 2015:166).

Untuk mengatasi hal tersebut dibutuhkan suatu inovasi yang nantinya dapat menumbuhkan kembali minat siswa untuk mempelajari IPA. Inovasi tersebut haruslah mengarah pada pelaksanaan pembelajaran yang menyenangkan dan merangsang minat siswa agar lebih berperan aktif, dengan harapan hal tersebut akan berdampak pada peningkatan minat, hasil dan prestasi belajarnya. Pembelajaran akan berjalan dengan lancar apabila dalam proses belajar dapat diterarpakan model pembelajaran, strategi pembelajaran, maupun metode pembelajaran yang tepat dalam kegiatan pembelajaran, salah satu model pembelajaran yang dapat membantu dalam melaksanakan proses pembelajaran yakni model pembelajaran Children's Learning In Science (CLIS) berbantuan media lingkungan.

Model pembelajaran Children's Learning In Science (CLIS) sering juga disebut model pembelajaran belajar IPA. Rangkaian fase pembelajaran pada model CLIS oleh Driver diberi nama general structure of a constructivist, sedangkan Tytler menyebutnya constructivism and conceptual change views of learning in science (Samatowa, 2011:74).

Model pembelajaran CLIS merupakan model pembelajaran yang berusaha mengembangkan ide atau gagasan siswa tentang suatu masalah tertentu dalam pembelajaran serta merekontruksi ide atau gagasan berdasarkan hasil pengamatan atau percobaan. Model pembelajaran tersebut dapat memberikan kesempatan pada siswa untuk lebih aktif dalam berkomunikasi atau berinteraksi langsung dengan lingkungan sekitar, sehingga dapat menambah pengalaman siswa dalam proses belajar (Alivfiani, 2010:3). Manfaat model pembelajaran CLIS adalah siswa dapat mengemukakan gagasan-gagasan awal, siswa membandingkan gagasannya dengan siswa lain, gagasan awal yang disampaikan dibuktikan dengan mempelajari topik pada buku teks, merekonstruksi gagasan baru melalui percobaan atau 
observasi, serta dapat menerapkan konsep yang telah ditemukan dengan cara menjawab pertanyaan yang berkaitan dengan dapat topik yang sedang dibahas (Tresna Dewi, 2014). Adapun kelebihan menggunakan model pembelajaran CLIS, yakni 1) gagasan siswa lebih mudah untuk dimunculkan, 2) pembelajaran berpusat pada siswa, 3) membiasakan siswa untuk belajar lebih aktif dan mandiri dalam memecahkan suatu permasalahan, 4) siswa menjadi aktif, kreatif dan terjadi kerjasama antara siswa selama kegiatan pembelajaran berlangsung, 5) menciptakan suasana bebas mengeluarkan pendapat saat proses pembelajaran berlangsung (Budiarti, 2014).

Berlangsungnya proses pembelajaran IPA di sekolah dasar tidak terlepas dengan lingkungan sekitar. Lingkungan inilah yang dapat dimanfaatkan di dalam proses pembelajaran untuk memanipulasi konsep-konsep menjadi lebih nyata. Lingkungan yang ada di sekitar siswa merupakan salah satu sumber belajar yang dapat dioptimalkan untuk pencapaian proses dan hasil pendidikan yang berkualitas. Sumber belajar lingkungan ini akan semakin memperkaya wawasan dan pengetahuan siswa karena mereka belajar tidak terbatas pada apa yang ada di dalam kelas. Lingkungan tanpa dibatasi ruang lingkupnya memiliki pengertian yang sangat luas dan komplek. Lingkungan sebagai sumber belajar diklasifikasikan menjadi empat kelompok yang terdiri dari klasifikasi sebagai berikut: (1) Lingkungan sosial adalah lingkungan masyarakat baik kelompok besar atau kelompok kecil; (2) Lingkungan alam (fisik) meliputi unsur-unsur biotik (makhluk hidup), abiotik (benda mati), dan semua sumber daya alam yang dapat diperdayakan sebagai sumber belajar; (3) Lingkungan personal meliputi individu-individu sebagai suatu pribadi berpengaruh terhadap individu pribadi lainnya; (4) Lingkungan kultural mencakup hasil budaya dan teknologi yang dapat dijadikan sumber belajar dan yang dapat menjadi faktor pendukung pengajaran, dalam konteks ini termasuk sistem nilai, norma dan adat istiadat (Prasojo, 2012:48). Terkait dengan hal tersebut Uno dan Nurdin (2014:146-147) berpendapat bahwa "lingkungan dapat digunakan sebagai sumber inspirasi dan motivator dalam meningkatkan pemahaman terhadap sesuatu yang dipelajari peserta didik yang berkaitan dengan lingkungan".

Menggunakan model pembelajran Children's Learning In Science Berbantuan Media Lingkungan dapat menciptakan suasana belajar yang aktif, kreatif, menarik, dan tidak membosankan bagi siswa. Penelitian ini bertujuan untuk mengetahui pengaruh model pembelajaran CLIS berbantuan media lingkungan terhadap hasil belajar IPA siswa kelas IV SD Gugus I Kuta Utara Tahun Ajaran 2016/2017

\section{Metode}

Penelitian ini dilaksanakan di kelas IV SD Gugus 1 Kuta Utara tahun ajaran 2016/2017. Jenis penelitian yang dilakukan adalah penelitian kuantitatif yakni penelitian eksperimen. Desain eksperimental yang digunakan pada penelitian ini yaitu Pre-Experimental Designs. Rancangan desain yang digunakan yaitu Intact-Group Comparison. Dalam rancangan ini, ada dua kelompok subjek yakni satu kelompok sebagai kelompok eksperimen dan satu kelompok sebagai kelompok kontrol.

Dalam sebuah penelitian, pemilihan populasi merupakan hal yang sangat diperlukan. Sugiyono (2011:80) menyatakan bahwa "populasi adalah wilayah generalisasi yang terdiri atas objek atau subjek yang mempunyai kualitas dan karakteristik tertentu yang diterapkan peneliti untuk dipelajari sehingga dapat ditarik kesimpulannya". Menurut Agung (2014:69), "Populasi adalah keseluruhan objek penelitian". Jadi kesimpulannya, populasi adalah keseluruhan dari objek yang diteliti untuk dipelajari dan ditarik kesimpulan. Populasi penelitian ini adalah seluruh siswa Kelas IV SD Gugus I Kuta Utara Kecamatan Badung yang masih menggunakan kurikulum KTSP yang terdiri dari 11 kelas dengan jumlah 386 siswa.

Dari penjelasan populasi tersebut, karena banyaknya anggota dalam satu gugus, sehingga tidak memungkinkan untuk meneliti semua objek yang ada di gugus tersebut maka dalam penelitian ini menggunakan sampel, untuk menentukan kelas yang akan dijadikan kelompok eksperimen dan kelompok kontrol. Setyosari (2015:221) menyebutkan bahwa "sampel adalah suatu kelompok yang lebih kecil atau bagian dari populasi secara keseluruhan". Sedangkan Agung (2014:69) juga menyebutkan bahwa "Sampel adalah sebagian dari populasi yang diambil, yang dianggap mewakili seluruh populasi". Jadi dapat di simpulkan bahwa sampel adalah suatu kelompok kecil yang di anggap $m$ ewakili seluruh populasi. Dalam penelitian ini teknik yang digunakan untuk menentukan sampel adalah teknik sampel kelompok. Teknik sampel kelompok merupakan sampel yang diambil dari kelompok-kelompok yang telah ditentukan, contohnya dengan menggunakan kelas. Teknik kelompok atau rumpun digunakan apabila populasi atau sampel yang tersedia berupa unit-unit rumpun dalam populasi. Pada pemilihan sampel tidak mengambil acak individu melainkan pengacakan kelas.

Penentuan sampel yang dijadikan kelompok ekserimen dan kelompok kontrol dilakukan dengan cara pengundian. Pengundian dilakukan agar semua anggota populasi memiliki kesempatan yang sama 
untuk dipilih menjadi sampel penelitian. Cara pengundian dilakukan dengan menulis semua nama kelas IV anggota populasi, setelah dilakukan pengundian diperoleh hasil dua kelompok yang akan digunakan sebagai sampel penelitian, yakni kelas IV di SD No. 5 Dalung dan kelas IVA di SD No. 6 Dalung. Kedua kelompok ini kemudian disetarakan dengan menggunakan teknik matching. Darmadi (2014:234) menyatakan bahwa, "matching adalah suatu teknik untuk menyeragamkan kelompok pada satu variabel atau lebih yang oleh peneliti telah diidentifikasikan mempunyai hubungan yang erat dengan variabel tidak bebas". Dalam penggunaan teknik matching setiap siswa dari dua kelompok yang telah dipilih dipasangkan berdasarkan nilai UTS yang sama. Dalam hal ini teknik yang dimaksud adalah memasangkan atau menjodohkan nilai UTS yang sama antara siswa di kelompok pertama dengan siswa di kelompok kedua, sehingga nilai masing-masing siswa pada kelompok pertama dan kelompok kedua dapat menyatakan bahwa kelompok tersebut setara. Jika terdapat siswa yang tidak mendapat pasangan maka siswa tersebut tidak diikutkan dalam penelitian tetapi tetap menerima perlakuan yang sama dan datanya tidak dianalisis.

Berdasarkan hasil analisis nilai UTS dengan menggunakan teknik matching, dari jumlah 45 siswa di SD No. 5 Dalung dan 39 siswa di SD No. 6 Dalung, diperoleh data nilai 36 siswa terbukti memiliki kemampuan yang setara secara akademik. Sehingga sampel yang diteliti dalam penelitian ini berjumlah 72 siswa, yaitu 36 siswa dari kelompok eksperimen dan 36 siswa dari kelompok kontrol yang dapat dinyatakan setara. Setelah sampel diketahui setara, maka selanjutnya dilakukan pengundian kembali diperoleh hasil SD No. 5 Dalung sebagai kelompok eksperimen dan SD No. 6 Dalung sebagai kelompok kontrol.

Validitas penelitian adalah kemampuan peneliti untuk mengungkapkan secara tepat yang ingin diteliti (Dantes, 2014:3). Validitas yang terkait dengan penelitian dapat dibedakan menjadi dua, yaitu validitas internal dan validitas eksternal.

Validitas internal dalam penelitian ini yaitu, karakteristik subjek, instrumentasi, sejarah , kematangan, dan sikap subjek. 1) Karakteristik Subjek, Pemilihan sampel penelitian, baik secara kelompok maupun perseorangan, dapat menghasilkan kelompok yang tidak homogen yang tidak diinginkan yang disebut dengan bias seleksi atau ancaman karakteristik subjek. Pada penelitian ini, karakteristik subjek dikendalikan dengan cara menghindari perbedaan karakteristik subjek dengan menggunakan teknik sampel kelompok untuk dijadikan sampel penelitian dalam bentuk kelompok bukan individu kemudian dilakukan penyetaraan kelompok menggunakan teknik matching. Selain itu, dapat di kendalikan dengan umur siswa yang sama yakni berkisar antara 10 - 11 tahun yang berada pada tahap perkembangan operasional konkret (7-12 tahun) dan memiliki kemampuan yang sama secara akademik. 2) Instrumentasi, Ancaman instrumentasi sering juga disebut implementer effect lebih banyak disebabkan karena faktor pelaku instrumen tersebut seperti penilai, observer, dan pewawancara. Oleh sebab itu, penggunaan instrumen dapat memberikan pengaruh terhadap hasil dalam melakukan penelitian. Pada penelitian ini ancaman instrumentasi dikendalikan dengan prosedur penelitian yang tepat dan instrumen yang dipakai peneliti harus diujicobakan terlebih dahulu. Instrumen yang digunakan adalah instrumen yang telah dijudges secara teoritik dan divalidasi secara empirik dengan hasil 28 soal yang valid, $\mathrm{r}_{11}=0,94$ (layak digunakan sebagai instrumen penelitian), hasil uji daya beda dengan diambil 25 orang dari kelompok atas dan kelompok bawah dan IKP = 0,41 (kriteria sedang). 3) Sejarah, Istilah sejarah merujuk pada peristiwa yang terjadi di sekitar atau lingkungan pada saat yang sama ketika variabel eksperimental tersebut dilakukan melalui pengujian. Pada penelitian ini ancaman sejarah dapat diatasi dengan cara guru yang melakukan perlakuan pada kelompok eksperimen dan kelompok kontrol memiliki kualifikasi jenjang pendidikan yang dimiliki guru sama atau setara, yaitu sama-sama sarjana pendidikan, kedua kelompok berpedoman pada kurikurul KTSP, dan materi IPA yang diajarkan materi di BAB IX tentang Kenampakan Bumi dan Benda Langit 4) Kematangan, merujuk pada proses perubahan yang terjadi dalam diri subjek. Suatu kematangan biologis tertentu ini terjadi karena seorang peserta didik memperhatikan guru dalam periode waktu yang lama. Untuk mengatasi hal ini maka dilakukan penelitian dengan penggunaan periode waktu yang sama dalam penelitian untuk kelompok kontrol dan kelompok eksperimen sehingga akan memiliki kesamaan pengalaman kematangan. Periode waktu yang digunakan adalah 6 kali pertemuan untuk melakukan perlakuan pada kelompok eksperimen dan kontrol. 6) Sikap subjek, pada penelitian dapat terjadi subjek menyadari dirinya menjadi partisipan dalam eksperimen sehingga timbul perasaan bangga karena ada yang memperhatikan apalagi diketahui bahwa penelitian ini adalah untuk memperbaiki keadaan subjek. Pada penelitian ini sikap subjek dapat diatasi dengan mengupayakan siswa agar mengganggap suatu hal yang rutin sehingga tidak perlu menimbulkan reaksi yang berlebihan, tidak membentuk kelas baru dan guru yang mengajar selama proses penelitian adalah guru kelas supaya siswa tidak mengagap kalau mereka sedang dijadikan objek penelitian. 
Selain faktor internal, ada faktor lain yang bersifat eksternal yang memiliki pengaruh pada hasil penelitiannya yaitu validitas eksternal. Validitas eksternal penelitian mengacu pada suatu hasil penelitian dapat digeneralisasikan. Menurut Dantes (2014:3) menyatakan validitas eksternal mengacu generalisasi populasi pada tingkat (kualitas) hasil penelitian. Ancaman validitas eksternal yang perlu diperhatikan pada penelitian ini, melakukan pemilihan anggota secara acak (random) dalam penentuan sampel agar dapat diperoleh sampel yang mewakili populasi. Teknik sampling yang digunakan teknik sampel kelompok dengan melakukan pengundian pada populasi yang sudah terbentuk dalam kelas-kelas, jadi setiap kelas dalam populasi memiliki peluang yang sama untuk dijadikan sampel penelitian. Hasilnya dapat digeneralisasikan pada populasi yaitu siswa kelas IV di SD Gugus 1 Kuta Utara.

Dalam penelitian ini, metode yang digunakan untuk mengumpulkan data hasil belajar adalah tes. Metode tes dipilih karena metode ini lebih banyak digunakan untuk mengevaluasi hasil belajar peserta didik dari segi ranah proses berpikir. Instrument yang digunakan untuk mengumpulkan data hasil belajar IPA adalah tes. Tes tertulis dapat dibedakan menjadi 2 (dua) bentuk, yakni tes objektif dan tes subjektif. Pada penelitian ini instrument yang digunakan untuk mengukur hasil belajar IPA adalah tes objektif dalam bentuk pilihan ganda. Menurut Agung (2011:34), butir soal pilihan ganda merupakan suatu butir yang alternatif jawabannya lebih dari dua. Pada umumnya jawaban berkisar antara 4 atau 5 option terdiri dari 28 butir soal yang telah divalidasi dengan melalui uji validitas, reliabilitas, daya beda dan tingkat kesukaran.

Pada penelitian ini, kelompok eksperimen diberikan perlakukan sebanyak 6 kali pertemuan dan diakhir eksperimen siswa diberikan pascates untuk memperoleh data hasil belajar IPA siswa. Data hasil belajar IPA siswa kemudian dianalisis menggunakan uji prasyarat yakni uji normalitas dengan rumus chi square dan uji homogenitas varians dengan uji $\mathrm{F}$ untuk mengetahui apakah kedua data yang diperoleh tersebut normal dan homogen. Hipotesis yang diuji adalah Hipotesis nol $\left(\mathrm{H}_{\mathrm{o}}\right)$ yang berbunyi tidak terdapat perbedaan yang signifikan hasil belajar IPA siswa yang dibelajarkan melalui model pembelajaran CLIS berbantuan media lingkungan dan siswa yang dibelajarkan melalui pembelajaran konvensional. Analisis statistik yang digunakan untuk menguji hipotesis penelitian adalah uji-t dengan rumus separated varian.

\section{Hasil dan Pembahasan}

Deskripsi data hasil belajar IPA pada kelompok eksperimen dan kelompok kontrol dapat dilihat pada tabel 1 berikut ini.

Tabel 1. Deskripsi Data Hasil Belajar IPA

\begin{tabular}{lll}
\hline Statistik & Kelompok Eksperimen & Kelompok Kontrol \\
\hline Mean & 83,83 & 74,33 \\
Standar Deviasi & 14,08 & 13,07 \\
Varian & 198,48 & 171,02 \\
Nilai Maksimum & 100 & 100 \\
Nilai Minimum & 50 & 46 \\
\hline
\end{tabular}

Berdasarkan tabel 1, rerata nilai hasil belajar IPA siswa kelompok eksperimen lebih dari rerata nilai hasil belajar IPA kelompok kontrol. Rerata nilai siswa kelompok eksperimen $\bar{X}=83,83$ dan rerata nilai siswa kelompok kontrol $\bar{X}=74,33$. Berdasarkan kriteria Penilaian Acuan Patokan (PAP) rerata kelompok eksperimen berada pada predikat Baik (B) sedangkan rerata kelompok kontrol berada pada predikat Cukup (C).

Sebelum melakukan uji hipotesis, harus dilakukan beberapa uji prasyarat, yaitu uji normalitas sebaran data dan uji homogenitas varians. Uji normalitas sebaran data dilakukan untuk membuktikan bahwa kedua data sampel penelitian berdistribusi normal. Rekapitulasi hasil analisis uji normalitas hasil belajar IPA kelompok eksperimen dan kelompok kontrol disajikan pada tabel 2 berikut ini. 
Tabel 2. Tabel Rekapitulasi Hasil Uji Normalitas Kelompok Eksperimen dan Kelompok Kontrol

\begin{tabular}{llll}
\hline Sampel & $\mathrm{X}^{2}$ hit & $\mathrm{X}^{2}$ tabel & Keterangan \\
\hline Kelompok Eksperimen & 5,92 & 11,070 & Berdistribusi Normal \\
Kelompok Kontrol & 3,55 & 11,070 & Berdistribusi Normal \\
\hline
\end{tabular}

Berdasarkan tabel 2, dapat dilihat hasil uji normalitas data hasil belajar IPA kelompok eksperimen $\mathrm{X}^{2}$ hitung $=5,92<\mathrm{X}^{2}$ tabel $=11,07$ pada taraf signifikansi $5 \%$ dengan $\mathrm{dk}=5$, maka data hasil belajar IPA kelompok eksperimen adalah berdistribusi normal. Sementara hasil uji normalitas data hasil belajar IPA siswa pada kelompok kontrol $\mathrm{X}^{2}$ hitung $=3,55<\mathrm{X}^{2}$ tabel $=11,07$ pada taraf signifikansi $5 \%$ dengan $\mathrm{dk}=5$, maka data hasil belajar IPA siswa untuk kelompok kontrol adalah berdistribusi normal. Setelah melakukan uji normalitas sebaran data, selanjutnya dilakukan Uji Homogenitas varians terhadap hasil belajar IPA siswa. Rekapitulasi hasil uji homogenitas dapat dilihat pada tabel 3 berikut ini.

Tabel 3. Tabel Hasil Uji Homogenitas Varian

\begin{tabular}{lllll}
\hline Sampel & Varians & Fhit & Ftabel & Kesimpulan \\
\hline Kelompok Eksperimen & 137,78 & 1,18 & 1,72 & Homogen \\
Kelompok Kontrol & 116,94 & 1, & & \\
\hline
\end{tabular}

Berdasarkan tabel 3, hasil uji homogenitas varian menunjukkan bahwa hasil belajar IPA yaitu $F_{\text {hitung }}=1,16$. kemudian dibandingkan dengan $F_{\text {tabel }}$ dengan $d k=36-1=35$ dan $d k=36-1=35$ dengan taraf signifikansi $5 \%(a=0,05)$, sehingga diperoleh $F_{\text {tabel }}=1,72$. Karena $F_{\text {hitung }}=1,56<\mathrm{F}_{\text {tabel }}$ $=1,72$, maka hasil belajar IPA siswa pada kelompok eksperimen dan kelompok kontrol mempunyai varians yang homogen.

Dari hasil uji prasyarat terhadap sebaran data yang telah dilakukan diperoleh bahwa data dari kelompok eksperimen dan kelompok kontrol berdistribusi normal dan homogen. Berdasarkan hal tersebut akan dilanjutkan terhadap pengujian pengujian hipotesis penelitian. Hipotesis penelitian yang diuji adalah $\mathrm{H}_{\mathrm{o}}$ yang berbunyi tidak terdapat perbedaan yang signifikan model pembelajaran children's learning in science berbantuan media lingkungan terhadap hasil belajar IPA siswa kelas IV SD Gugus 1 Kuta Utara Tahun Ajaran 2016/2017. Berdasarkan hasil uji normalitas dan homogenitas varians diperoleh data bahwa kelompok eksperimen dan kelompok kontrol berdistribusi normal serta homogen dan jumlah anggota sampel sama $\left(\mathrm{n}_{1}=\mathrm{n}_{2}\right)$. Berdasarkan hal tersebut maka uji statistik yang digunakan dalam penelitian ini adalah uji-t dengan rumus separated varians. Dengan kriteria jika thitung $\leq \mathrm{t}$ tabel, maka $\mathrm{H}_{\mathrm{o}}$ diterima, dan jika thitung $>$ ttabel maka $\mathrm{H}_{\mathrm{o}}$ ditolak. Pada taraf signifikan $5 \%$ dengan $\mathrm{dk}=\mathrm{n}_{1}+\mathrm{n}_{2}-2$. Rekapitulasi hasil perhitungan uji hipotesis disajikan pada tabel 4 berikut ini.

Tabel 4. Rekapitulasi Hasil Perhitungan Uji Hipotesis

\begin{tabular}{|c|c|c|c|c|c|c|}
\hline Sampel & Mean & Varian & $\mathrm{N}$ & $t_{\text {hitung }}$ & $t_{\text {tabel }}$ & Kesimpulan \\
\hline $\begin{array}{l}\text { Kelompok } \\
\text { Eksperimen }\end{array}$ & 83,83 & 198,48 & 36 & \multirow{2}{*}{2,96} & \multirow{2}{*}{2,000} & \multirow{2}{*}{$\mathrm{H}_{\mathrm{o}}$ ditolak } \\
\hline $\begin{array}{l}\text { Kelompok } \\
\text { Kontrol }\end{array}$ & 74,33 & 171,02 & 36 & & & \\
\hline
\end{tabular}

Berdasarkan tabel 4 , analisis uji $\mathrm{t}$ yang telah dilakukan diperoleh hasil $\mathrm{t}_{\text {hitung }}=2,96$ sedangkan pada taraf signifikansi $5 \%$ dengan $\mathrm{dk}=\mathrm{n} 1+\mathrm{n} 2-2=(36+36-2)=70$ diperoleh tabel $=$ 2,00. Oleh karena nilai thitung $=2,96>t_{\text {tabel }}=2,00$, maka $\mathbf{H}_{\mathbf{o}}$ ditolak. Berdasarkan hasil analisis yang telah dilakukan, karena nilai thitung $=2,96>$ tabel $=2,00$, maka $\mathrm{H}_{0}$ ditolak dan $\mathrm{H}_{\mathrm{a}}$ diterima. Hal ini berarti terdapat perbedaan yang signifikan hasil belajar IPA antara kelompok eksperimen dan kelompok kontrol pada kelas IV SD Gugus 1 Kuta Utara Tahun Ajaran 2016/2017. 


\section{Hasil dan Pembahasan}

Setelah menganalisis data pascates, diketahui bahwa sebaran data hasil belajar IPA berdistribusi normal dan memiliki varian yang homogen. Dari hasil analisis diperoleh thitung $=$ 2,96. Harga tersebut kemudian dibandingkan dengan harga tabel dengan $\mathrm{dk}=36+36-2=70$ dan taraf signifikansi $5 \%$ sehingga diperoleh harga tabel $=2,000$, karena thitung $=2,96>$ tabel $=2,000$ maka $\mathbf{H}_{\mathbf{o}}$ ditolak. Ini berarti terdapat perbedaan yang signifikan hasil belajar IPA siswa yang dibelajarkan melalui model pembelajaran CLIS berbantuan media lingkungan dan siswa yang dibelajarkan melalui pembelajaran konvensional.

Secara deskriptif, rerata nilai hasil belajar IPA siswa kelompok eksperimen lebih dari rerata nilai hasil belajar IPA kelompok kontrol. Rerata nilai siswa kelompok eksperimen yaitu $\bar{X}=83,83$ lebih dari rerata nilai siswa kelompok kontrol yaitu $\bar{X}=74,33$. Berdasarkan kriteria Penilaian Acuan Patokan (PAP) rerata kelompok eksperimen berada pada kriteria Baik (B) sedangkan rerata kelompok kontrol berada pada kriteria Cukup (C). Ini berarti bahwa model pembelajaran CLIS berbantuan media lingkungan berpengaruh terhadap hasil belajar IPA siswa kelas IV SD Gugus 1 Kuta Utara Kecamatan Badung Tahun Ajaran 2016/2017.

Perbedaan yang signifikan hasil belajar IPA siswa yang dibelajarkan melalui model pembelajaran CLIS berbantuan media lingkungan disebabkan karena model pembelajaran ini memberikan kesempatan pada siswa untuk mengembangkan ide atau gagasan tentang suatu masalah tertentu dalam pembelajaran serta merekontruksi ide atau gagasan berdasarkan hasil pengematan dan memperoleh pengalaman langsung dengan objek dan interaksi sosial dalam kelompoknya saat mencocokkan konsepsi awalnya dengan konsep yang disepakati ilmuwan. Ditambah lagi dengan menggunakan media lingkungan, siswa dapat menemukan hubungan yang sangat bermakna antara ide-ide abstrak dan penerapan praktis di dalam konteks dunia nyata, konsep dipahami melalui proses penemuan, pemerdayaan dan hubungan. Pada kelompok kontrol diberikan pembelajaran konvensional yakni dengan menggunakan EEK (eksplorasi, elaborasi dan konfirmasi). Menggabungkan model pembelajaran dengan media tersebut akan semakin menambah ketertarikan siswa untuk belajar. Maka dengan diterapkannya model pembelajaran CLIS berbantuan media lingkungan berpengaruh positif terhadap hasil belajar siswa.

Hasil penelitian ini diperkuat penelitian yang dilakukan oleh Ambarwati (2016), dengan hasil penelitian yang menyatakan bahwa, hasil analisis data post-test menunjukkan terdapat perbedaan pemahaman konsep IPA kelompok siswa yang mengikuti pembelajaran dengan model pembelajaran CLIS dan kelompok siswa yang mengikuti pembelajaran dengan model pembelajaran konvensional. Hasil ini juga didasarkan pada rata-rata skor post-test siswa. Rata-rata skor post-test siswa yang mengik uti pembelajaran dengan model pembelajaran CLIS adalah 23,33 dan rata-rata skor post-test siswa yang mengikuti pembelajaran dengan model pembelajaran konvensional adalah 18,27. Selanjutnya berdasarkan analisis data menggunakan uji-t, diketahui thitung $=3,86$ dan pada taraf signifikasi $5 \%$ dengan $\mathrm{dk}=38 \mathrm{t}_{\text {tabel }}=2,021$. Hasil perhitungan tersebut menunjukan bahwa thitung lebih dari tabel $(3,86>2,021)$, sehingga hasil penelitian adalah signifikan. Hal ini berarti, terdapat perbedaan yang signifikan pada pemahaman konsep IPA antara kelompok siswa yang mengikuti pembelajaran dengan model pembelajaran CLIS dan kelompok siswa yang mengikuti pembelajaran dengan model pembelajaran konvensional. Selain itu, didukung juga oleh hasil penelitian Yastini Dewi (2013), yang menyatakan bahwa, model pembelajaran quantum bermedia lingkungan yang diterapkan pada kelompok eksperimen telah berhasil memberikan pengaruh yang signifikan terhadap pemahaman konsep siswa. Model pembelajaran quantum bermedia lingkungan menunjukkan perbedaan yang signifikan. Hal ini dapat dilihat dari hasil analisis data menggunakan uji-t polled varians diperoleh $t_{\text {hitung }}=5,761>t_{\text {tabel }}=2,004$ pada taraf signifikansi $5 \%$. Hal ini berarti, terdapat perbedaan pemahaman konsep energi siswa antara siswa yang dibelajarkan menggunakan model pembelajaran quantum bermedia lingkungan dan siswa yang dibelajarkan menggunakan model pengajaran langsung (direct instruction).

Berdasarkan pemaparan tersebut, dapat disimpulkan bahwa model pembelajaran CLIS berbantuan media lingkungan berpengaruh terhadap hasil belajar IPA siswa kelas IV SD Gugus 1 Kuta Utara Kecamatan Badung Tahun Ajaran 2016/2017. 


\section{Simpulan dan Saran}

Berdasarkan kriteria PAP skala lima rata-rata hasil belajar IPA pada kelompok eksperimen berada pada kategori baik (B). Hal ini dibuktikan dari hasil analisis data hasil belajar IPA diperoleh rata-rata yaitu 83,83 . Setelah dikonversikan rata-rata persentase yang diperoleh yaitu $83,83 \%$ dengan kriteria PAP skala lima, berada pada persentase pencapain $80-89$.

Berdasarkan kriteria PAP skala lima rata-rata hasil belajar IPA pada kelompok kontrol berada pada kategori cukup (C). Hal ini dibuktikan dari hasil analisis data hasil belajar IPA diperoleh rata-rata yaitu 74,33 . Setelah dikonversikan rata-rata persentase yang diperoleh yaitu 74,33\% dengan kriteria PAP skala lima, berada pada persentase pencapain $65-79$.

Model pembelajaran CLIS berbantuan media lingkungan berpengaruh terhadap hasil belajar IPA siswa kelas IV SD Gugus 1 Kuta Utara Tahun Ajaran 2016/2017. Hal ini terbukti dari hasil analisis dengan menggunakan uji-t diperoleh thitung $=2,96$ dengan $\mathrm{dk}=70$ pada taraf signifikansi $5 \%$ diperoleh ttabel $=2,000$ sehingga 2,96 $>2,000$. Selain itu rata-rata siswa kelompok eksperimen lebih dari rata-rata siswa kelompok kontrol, $\bar{X}=83,83>\bar{X}=74,33$.

Adapun saran yang dapat disampaikan setelah melaksanakan dan memperoleh hasil dari penelitian yaitu kepada Guru, dengan diadakannya penelitian ini, disarankan kepada guru agar lebih kreatif untuk memberikan fasilitas berupa sumber belajar dan kesempatan yang lebih besar bagi siswa pada pembelajaran dengan menggunakan model pembelajaran CLIS berbantuan media lingkungan sehingga tercipta pembelajaran bermakna dan menyenangkan bagi siswa. Kepada Kepala Sekolah, hasil penelitian ini diharapkan dapat dijadikan pedoman bagi sekolah untuk menciptakan kondisi yang mampu memotivasi dan meningkatkan kualitas guru dalam merancang pembelajaran yang inovatif, sehingga dapat meningkatkan mutu dan kualitas sekolah menjadi lebih unggul dan inovatif. Kepada Peneliti Lain, dengan dilakukannya penelitian ini, disarankan kepada peneliti lain hasil penelitian ini digunakan sebagai referensi untuk melaksanakan penelitian selanjutnya atau menemukan inovasi kegiatan pembelajaran lainnya yang lebih bermakna dan menyenangkan bagi siswa.

\section{Daftar Rujukan}

Agung, A.A Gede. 2011. Pengantar Evaluasi Pendidikan. Singaraja: Universitas Pendidikan Ganesha

Agung, A.A Gede. 2014. Metodologi Penelitian Pendidikan. Yogyakarta: Aditya Media Publishing

Alifviani, Inyatul. 2010. “Penerapan Model Pembelajaran Children's Learning In Science (CLIS) Untuk Meningkatkan Keterampilan Berpikir Ilmiah Siswa Kelas IV SD Negeri Kedungmutih 1 Demak". Tersedia pada http://lib.unnes.ac.id/2963/1/6513.pdf (Diakses pada Tahun 2010).

Ambarwati, Kadek Nila. 2016. "Pengaruh Model Pembelajaran Children Learning In Science Terhadap Pemahaman Konsep IPA Siswa Kelas IV SD". Jurusan Pendidikan Guru Sekolah Dasar FIP Undiksha. Volume 4, Nomor 1.

Budiarti, Luh Putu Yudha. 2014. "Pengaruh Model Pembelajaran CLIS Terhadap Hasil Belajar IPA Siswa Kelas IV SD Di Gugus III Kecamatan Busungbiu". Jurusan Pendidikan Guru Sekolah Dasar FIP Undiksha. Volume 2, Nomor 1. 
Dantes, Nyoman. 2014. Analisis Dan Desain Eksperimen. Singaraja: Program Pascasarjana Undiksha. Darmadi, Hamid. 2014. Metode Penelitian Pendidikan dan Sosial. Bandung: Alfabeta, cv.

Dewi, Ni Pt Yastini. 2013. "Pengaruh Model Pembelajaran Quantum Bermedia Lingkungan Terhadap Pemahaman Konsep Energi Di SD Negeri 1 Banyuning". Jurusan Pendidikan Guru Sekolah Dasar FIP Undiksha. Volume 1, Nomor 1.

Prasojo, Edi. 2012. "Peningkatan Kualitas Pembelajaran IPA Melalui Metode Eksperimen Berbasis Lingkungan Siswa Kelas IV SDN Ngalian 01 Semarang". Tersedia pada http://lib.unnes.ac.id/18808/1/1402408073.pdf (Diakses pada Tahun 2017).

Samatowa, Usman. 2011. Pembelajaran IPA di Sekolah Dasar. Jakarta: PT Indeks.

Setyosari, Punaji. 2015 Metode Penelitian Pendidikan \& Pengembangan. Jakarta: PrenandaMedia Group

Sugiyono.2011. Metode Penelitian Pendidikan. Bandung: Alfabeta, cv

Susanto, Ahmad. 2015. Teori Belajar dan Pembelajaran di Sekolah Dasar. Jakarta: PrenandaMedia Group

Tresna Dewi, Pande Nym Tri. 2014. “ Pengaruh Model Children's Learning In Science Berbantuan Media Powerpoint Terhadap Hasil Belajarv IPA Siswa Kela V SD". Jurusan Pendidikan Guru Sekolah Dasar FIP Undiksha. Volume 2. Nomor 1.(hlm 1-10)

Undang-undang No. 20 Tahun 2003 tentang Sistem Pendidikan Nasional. Jakarta: Departemen Pendidikan Nasional

Uno, Hamzah dan Nurdin Mohamad. 2014. Belajar dengan Pendekatan PAILKEM. Jakarta: Bumi Aksara. 